\title{
Validation of ash optical depth and layer height retrieved from passive satellite sensors using EARLINET and airborne lidar data: the case of the Eyjafjallajökull eruption
}

\author{
Dimitris Balis ${ }^{1}$, Maria-Elissavet Koukouli ${ }^{1}$, Nikolaos Siomos ${ }^{1}$, Spyridon Dimopoulos ${ }^{1}$, Lucia Mona $^{2}$, \\ Gelsomina Pappalardo $^{2}$, Franco Marenco ${ }^{3}$, Lieven Clarisse ${ }^{4}$, Lucy J. Ventress ${ }^{5}$, Elisa Carboni ${ }^{6}$, Roy G. Grainger ${ }^{6}$, \\ Ping Wang ${ }^{7}$, Gijsbert Tilstra ${ }^{7}$, Ronald van $\operatorname{der} \mathbf{A}^{7}$, Nicolas Theys ${ }^{8}$, and Claus Zehner ${ }^{9}$ \\ ${ }^{1}$ Laboratory of Atmospheric Physics, Aristotle University of Thessaloniki, Thessaloniki, Greece \\ ${ }^{2}$ Consiglio Nazionale delle Ricerche, Istituto di Metodologie per l'Analisi Ambientale (CNR-IMAA), \\ Tito Scalo, Potenza, Italy \\ ${ }^{3}$ Met Office, Exeter, UK \\ ${ }^{4}$ Université Libre de Bruxelles, Brussels, Belgium \\ ${ }^{5}$ National Centre for Earth Observation, Atmospheric, Oceanic and Planetary Physics, University of Oxford, Oxford, UK \\ ${ }^{6}$ COMET, Atmospheric, Oceanic and Planetary Physics, University of Oxford, Oxford, UK \\ ${ }^{7}$ Royal Netherlands Meteorological Institute (KNMI), De Bilt, the Netherlands \\ ${ }^{8}$ Belgian Institute for Space Aeronomy (IASB-BIRA), Brussels, Belgium \\ ${ }^{9}$ European Space Agency, ESRIN, Frascati, Italy \\ Correspondence to: Dimitris Balis (balis@auth.gr)
}

Received: 22 December 2015 - Published in Atmos. Chem. Phys. Discuss.: 19 January 2016

Revised: 26 April 2016 - Accepted: 27 April 2016 - Published: 10 May 2016

\begin{abstract}
The vulnerability of the European airspace to volcanic eruptions was brought to the attention of the public and the scientific community by the 2010 eruptions of the Icelandic volcano Eyjafjallajökull. As a consequence of this event, ash concentration thresholds replaced the "zero tolerance to ash" rule, drastically changing the requirements on satellite ash retrievals. In response to that, the ESA funded several projects aiming at creating an optimal end-to-end system for volcanic ash plume monitoring and prediction. Two of them, namely the SACS-2 and SMASH projects, developed and improved dedicated satellite-derived ash plume and sulfur dioxide level assessments. The validation of volcanic ash levels and height extracted from the GOME-2 and IASI instruments on board the MetOp-A satellite is presented in this work. EARLINET lidar measurements are compared to different satellite retrievals for two eruptive episodes in April and May 2010. Comparisons were also made between satellite retrievals and aircraft lidar data obtained with the UK's BAe-146-301 Atmospheric Research Aircraft (managed by the Facility for Airborne Atmospheric Measure-
\end{abstract}

ments, FAAM) over the United Kingdom and the surrounding regions. The validation results are promising for most satellite products and are within the estimated uncertainties of each of the comparative data sets, but more collocation scenes would be desirable to perform a comprehensive statistical analysis. The satellite estimates and the validation data sets are better correlated for high ash optical depth values, with correlation coefficients greater than 0.8 . The IASI retrievals show a better agreement concerning the ash optical depth and ash layer height when compared with the groundbased and airborne lidar data.

\section{Introduction}

The Eyjafjallajökull volcano in Iceland $\left(63.63^{\circ} \mathrm{N}, 19.62^{\circ} \mathrm{W}\right)$ erupted on 14 April 2010 and the ash-loaded plume rose to more than $10 \mathrm{~km}$, deflected to the east by westerly winds (Stohl et al., 2011). The plume persisted over central Europe from 15 and 26 April 2010, while occasionally extend- 
ing to south-east Europe (Emeis et al., 2011). New significant eruptions occurred between 4 and 9 May as well as 14 and 19 May 2010 (Gudmudsson et al., 2010). The first of these phases mainly influenced western Europe, from Great Britain to the Iberian Peninsula, while the second phase influenced central Europe and the central and eastern Mediterranean on 18-22 May. The last observations of the event were recorded over central Europe on 25 May (Gudmundsson et al., 2010). Although the eruption was a moderate one in terms of volcanic explosivity, due to advection of the volcanic ash plumes, civil aviation was shut down for many days over numerous European countries (Gertisser, 2010) and thus in terms of economic costs was more severe. This resulted in an urgent demand for reliable model forecasts of the vertical and horizontal extent of the ash plume, and for complementary measurements that could be used for nowcasting and forecast verification (Sears et al., 2013). Following an eruption, Volcanic Ash Advisory Centres (VAACs) distributed around the globe give instructions to civil aviation in order avoid potential hazards (e.g. Guffanti et al., 2010). Considering the large social and economic impact of any decision, the provided guidelines should be reliable and verifiable and should use all available scientific information (Zehner, 2012). During the eruption period the European Aerosol Research Lidar Network, EARLINET, responded to this demand with coordinated intensive measurements from ground-based lidar (e.g. Ansmann et al., 2010, 2011; Groß et al., 2011; Mona et al., 2012; Papayannis et al., 2012; Perrone et al., 2012; Navas-Guzman et al., 2013; Pappalardo et al., 2013; Trickl et al., 2013; Wiegner et al., 2012), initially by providing quick-look images and identification of the volcanic ash layers. This observation campaign provided information on ash height and its vertical extent, as well as an estimation of the ash load in terms of optical depth and mass concentration. In addition, there were a number of dedicated airborne campaigns during the eruption that combined lidar and in situ measurements of the ash plume (e.g. Marenco et al., 2011; Schumann et al., 2011; Chazette et al., 2012). The volcanic plume was observed from a variety of satellite instruments such as the Cloud-Aerosol Lidar with Orthogonal Polarization (CALIOP) on board the CALIPSO satellite (Winker et al., 2012) and a number of passive satellite sensors either in low Earth orbit, such as GOME-2/MetOp-A (e.g. Rix et al., 2012), MODIS/Terra and MODIS/Aqua (e.g. Christopher et al., 2012) and IASI/MetOp-A (Carboni et al., 2012), or in geostationary orbit, such as SEVIRI (e.g. Francis et al., 2012). The World Meteorological Organization organized an intercomparison campaign of 22 satellite-based volcanic ash retrieval algorithms applied on passive sensors (WMO, 2015). The intercomparison was based on six selected volcanic eruptions including Eyjafjallajökull. Validation results showed variable agreement with lidar data, depending upon the scene conditions.

In 2012 the European Space Agency (ESA) initiated the project "Satellite Monitoring of Ash and Sulphur Dioxide for the mitigation of Aviation Hazards" (SACS-2) to support authorities and the VAACs during future volcanic events. The project created an optimal end-to-end system for volcanic ash plume monitoring and prediction (Brenot et al., 2014 and http://sacs.aeronomie.be). The system is based on improved and dedicated satellite-derived ash plume and sulfur dioxide products, followed by extensive validation using satellite and ground-based measurements (Koukouli et al., 2014a; Spinetti et al., 2014). In this paper, we present validation results for two satellite sensors, GOME-2/MetOp-A and IASI/MetOpA, concerning the volcanic ash optical depth and ash layer height, using ground and aircraft lidar measurements. The comparisons are restricted to the Eyjafjallajökull eruption period of 2010. In the first section we provide a short description of the satellite data and then a description of the groundbased and aircraft lidar data used as a reference for validation. Then we describe the methodology applied in the comparisons, and the collocation criteria applied. In the second section, we present the comparison results for the different sensors and algorithms, separately for the ground-based and aircraft data. Finally, we discuss the results and summarize our findings.

\section{Data and methodology}

\subsection{Satellite data}

One of the main tasks of ESA's SACS-2 and SMASH (Satellite Monitoring of Ash and Sulphur dioxide for the mitigation of aviation Hazards) projects was to improve and validate the algorithms for the retrieval of ash optical depth and height, using satellite measurements in the infrared and UVvisible from low Earth orbit sensors. These improvements were based on previous algorithm developments (e.g. de Graaf et al., 2005; Clerbaux et al., 2009; Clarisse et al., 2010, 2013; Gangale et al., 2010; Carboni et al., 2012; Grainger et al., 2013). In this paper we use data from GOME-2 and IASI instruments on board the MetOp-A satellite which covered the whole eruption period of Eyjafjallajökull in 2010. Details of the satellite data are described below.

\subsubsection{GOME-2/MetOp-A}

The Global Ozone Monitoring Experiment-2 (GOME-2) is a visible-ultraviolet scanning spectrometer featuring 4096 channels and 200 polarization channels in the 240$790 \mathrm{~nm}$ spectral range, and featuring a $40 \mathrm{~km} \times 40 \mathrm{~km}$ resolution. Data from GOME-2/MetOp-A have been processed by the Royal Netherlands Meteorological Institute (KNMI). The volcanic ash retrieval algorithm includes an estimation of the optical depth of an ash layer based on the absorbing aerosol index (AAI) (Herman et al., 1997; Torres et al., 1998) as well as an estimation of the effective ash layer height. The algorithm is based on look-up tables formed in terms of the AAI, aerosol height, solar zenith angle (SZA), viewing 
zenith angle (VZA), and relative azimuth angle (RAZI). The AAI is sensitive to atmospheric parameters such as aerosol type, aerosol layer height, and aerosol optical depth (AOD), and surface height and scattering geometry (de Graaf et al., 2005). The most dominant parameters are aerosol optical thickness and aerosol layer height. In general, thick aerosol layers produce larger AAI values than thin aerosol layers, while high-altitude aerosol layers produce larger AAI values than low-lying aerosol layers (Torres et al., 1998; de Graaf et al., 2005). If the aerosol type, surface albedo, and geometries (SZA, VZA, RAZI) are known, aerosol optical thickness can be calculated using the AAI and aerosol height. The ash layer height is derived using the Fast REtrieval Scheme for Clouds from Oxygen A-band (FRESCO) algorithm (P. Wang et al., 2008). It has been demonstrated that FRESCO can retrieve volcanic ash layer height for optically thick ash plumes (Wang et al., 2012). The retrieved optical thickness of the ash layer depends on the assumption of aerosol properties used in the look-up tables (LUTs). The volcanic ash particles are assumed to be spherical and have a bimodal log-normal size distribution. In our calculations, we used an effective radius of $0.052 \mu \mathrm{m}$ and effective variance of $1.697 \mu \mathrm{m}$ for the fine mode, and an effective radius of $0.67 \mu \mathrm{m}$ and effective variance of $1.806 \mu \mathrm{m}$ for the coarse mode. The weight of the fine mode was 0.995 . Two different a priori assumptions for the refractive index of strongly absorbing volcanic ash were tested, indicated later on as DUST and VOLZ (Volz, 1973; Sinyuk et al., 2003).

\subsubsection{IASI/MetOp-A}

The Infrared Atmospheric Sounding Interferometer (IASI) is an infrared spectrometer featuring 8461 channels in the $645-2760 \mathrm{~cm}^{-1}$ spectral range, with a spectral resolution of $0.25 \mathrm{~cm}^{-1}$. Satellite estimates for the ash optical depth and layer height from IASI/MetOp-A have been provided by two institutes, the Universite Libre de Bruxelles (ULB) and the University of Oxford (UOXF).

\section{ULB algorithm}

The data set provided by the ULB was generated by a LUTbased algorithm described in Moxnes et al. (2014) using two distinct sets of refractive indices: one set provided by Dan Peters (personal communication, 2014) based on recent measurements of Eyjafjallajökull ash, and the other set using the basaltic ash refractive index data from Pollack et al. (1973; referred to as the Eyja and Pollack data sets respectively). In this paper we show only estimates based on the Eyja refractive index. The index was available with a spectral resolution of $1 \mathrm{~cm}^{-1}$. The algorithm assumes a log-normal particle size distribution with a spread of 2 . The mode radius is retrieved together with the ash optical depth. For this eruption, the ash plume was assumed to be centred at $5 \mathrm{~km}$ and no attempt was made to retrieve ash plume height.

\section{UOXF algorithm}

The data sets provided by UOXF also assume the Eyja refractive index, and treat similar the particle size distribution. The algorithmic processing of UOXF resulted in four different products: one characterized as the "iterative" algorithm, which provided ash optical depth and layer height, and three characterized as the "fast" algorithm, which provided ash optical depth for three fixed volcanic ash layer pressures (400, 600 and $800 \mathrm{hPa}$ ). The fast algorithm, based on the method of Walker et al. (2011), carries out a linear retrieval (leastsquares fit) of the aerosol optical depth, AOD, assuming a fixed plume altitude and effective radius. The algorithm looks for departures in the measured spectra from an expected background covariance, created from previous IASI measurements containing no volcanic ash. The iterative algorithm is a full optimal estimation retrieval using a forward model based on Radiative Transfer for TOVS (TIROS Operational Vertical Sounder), RTTOV, a very fast radiative transfer model for nadir-viewing passive visible, infrared and microwave satellite radiometers. Clear-sky radiances from RTTOV are combined with an ash layer in a method described in detail by Thomas et al. (2009a, b). The iterative scheme then provides probable values of AOD, effective radius and plume altitude (Ventress et al., 2016). The fast algorithm is used to flag IASI pixels (assuming an AOD threshold defined by the statistics of the scene) for the presence of volcanic ash, at which point the iterative retrieval is carried out on the pixel.

\subsection{Lidar data}

The validation of the satellite products used lidar measurements from two sources. The first was the intensive groundbased lidar measurements from stations that form the European Research Lidar Network (EARLINET) and the second was the airborne lidar measurements from the UK's BAe146-301 Atmospheric Research Aircraft, managed by the Facility for Airborne Atmospheric Measurements (FAAM). The airborne measurements captured larger volcanic ash load than the ground-based network, and this is explained by the fact that the former is a moving platform that was tasked with overflying the areas with large concentrations. The aircraft flights monitored a large area affected by the ash cloud. At the same time, for most of the EARLINET stations, the volcanic particles atmospheric content was almost half of that observed in the UK, which was directly downwind from the eruption.

In the next section we provide a brief description of the lidar measurements used as reference data for the validation of the satellite products. 


\subsubsection{EARLINET data}

The European Aerosol Research Lidar Network (EARLINET) has coordinated ground-based lidar activities on the European continent since 2000, and it holds a comprehensive database of European lidar data sets giving information on the horizontal, vertical and temporal distribution of aerosols on a continental scale. Lidar data from the EARLINET network (Pappalardo et al., 2014, and http://www.earlinet.org) were used to validate ash plume height and optical depth. EARLINET was established in 2000 and is the first aerosol lidar network with the main goal of providing data for investigating the aerosol distribution on a continental scale. EARLINET has established certain protocols for the measurements and quality control of the systems and retrieved data, through algorithm (Böckmann et al., 2004; Pappalardo et al., 2004) and system (Matthias et al., 2004a; Freudenthaler et al., 2010; Wandinger et al., 2016) intercomparison campaigns. The network currently includes 27 stations distributed over the European continent. The standard products of EARLINET include aerosol extinction and backscatter profiles. EARLINET data have been widely used for climatological studies (e.g. Matthias et al., 2004b; Amiridis et al., 2005; Giannakaki et al., 2007) as well as for monitoring unusual atmospheric events such as desert dust, biomass burning, pollution episodes, and volcanic eruptions. Results have been presented in numerous publications (e.g. Amiridis et al., 2009; Ansmann et al., 2003; Guerrero-Rascado et al., 2009; Mamouri et al., 2012; Mattis et al., 2010; Mona et al., 2006; Müller et al., 2007; Papayannis et al., 2008; X. Wang et al., 2008).

A relational database, containing the output of the 4-D analysis of EARLINET data related to the volcanic eruption of 2010, has been set up (Mona et al., 2012; Pappalardo et al., 2013) and is freely available on request at http://www.earlinet.org. Information related to the present study involves aerosol backscatter coefficient profiles for each of the ground-based stations (EARLINET publishing group 2000-2010, 2014), as well as a characterization of the observed layers as pure volcanic or mixed (Pappalardo et al., 2013). A volcanic aerosol mask was developed (Mona et al., 2012), which involved aerosol typing, back-trajectory analyses and model outputs, used together with the lidar measurements at $1 \mathrm{~h}$ temporal resolution. The data included in the EARLINET database captured the whole Eyjafjallajökull eruptive event over Europe, providing geometrical and optical properties of the tropospheric volcanic cloud. The volcanic cloud persisted over central Europe for the whole period at heights of between 3 and $8 \mathrm{~km}$, with maximum load observed on 16 April 2010 over Hamburg (Pappalardo et al., 2013). In our study we only used profiles that were detected as pure volcanic, as these were characterized by the methodology applied in Pappalardo et al. (2013). The list of stations considered for the validation of the satellite products is shown in Table 1.

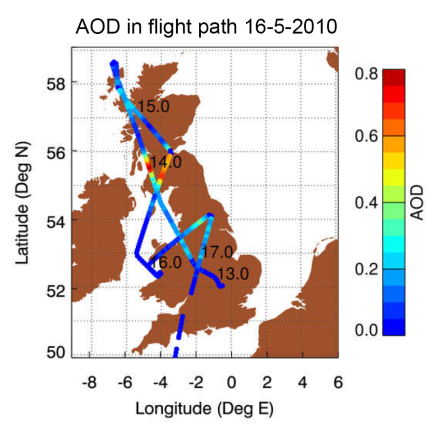

(a)

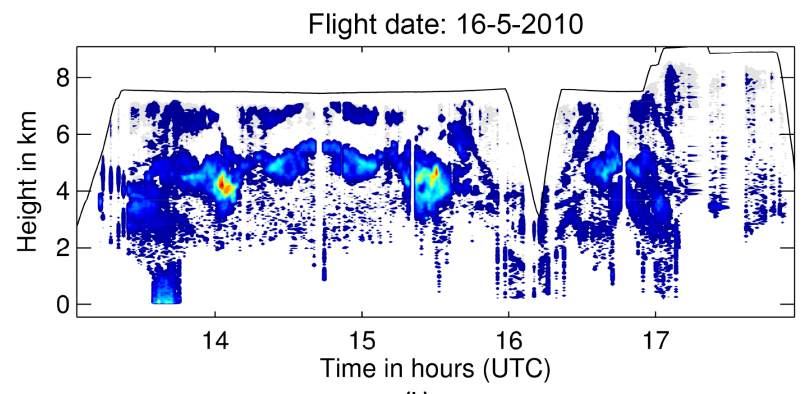

(b)

Figure 1. Characteristics of the FAAM flight of 16 May 2010. The flight track coloured according to AOD (a), and the flight altitude vs. time in UTC along with a time-altitude cross section for the aerosol extinction coefficient at $355 \mathrm{~nm}$ (in $\mathrm{Mm}^{-1}$ ) measured with the aircraft lidar (b).

\subsubsection{Airborne lidar data}

The satellite products are validated using lidar measurements from six flights by the UK's BAe-146-301 Atmospheric Research Aircraft over the United Kingdom and the surrounding seas in May 2010 (e.g. Marenco et al., 2011; Johnson et al., 2011). The lidar measurements include aerosol extinction profiles at $355 \mathrm{~nm}$, which in turn provide plume height and layer optical depth. Measurements were integrated to a vertical resolution of $45 \mathrm{~m}$ and a temporal resolution of 1 min (corresponding to a typical $\sim 9 \mathrm{~km}$ horizontal resolution), and all lidar profiles have been cloud-screened. An extinction-to-backscatter ratio (lidar ratio) of $60 \mathrm{sr}$ was used for the inversion of lidar signals; this lidar ratio was determined in such a way as to satisfy the constraints of a molecular signal below and above lofted layers. In situ observations were provided by other probes on the aircraft, in particular a three-wavelength nephelometer, a passive cavity aerosol spectrometer probe (PCASP) and a cloud and aerosol spectrometer (CAS) optical particle counters; radiative measurements were taken in the visible and infrared. An example of the available aerosol extinction profiles, along with flight altitude and flight track, is shown in Fig. 1 for 16 May 2010. The data shown here will be discussed in more detail in the overview of the comparison results. In this paper we mainly used lidar data from 4, 5, 14, 16, 17 and 18 May 2010 flights, 
Table 1. Locations of EARLINET lidar stations, their geographical coordinates and corresponding domain assigned (C: central Europe; N: north-central Europe; SW: Iberian Peninsula; SE: Italy-Balkans).

\begin{tabular}{|c|c|c|c|c|}
\hline Site & $\begin{array}{r}\text { Altitude a.s.l. } \\
(\mathrm{m})\end{array}$ & $\begin{array}{l}\text { Lat } \\
(\mathrm{N})\end{array}$ & $\begin{array}{r}\text { Long } \\
(\mathrm{E})\end{array}$ & Domain \\
\hline Andøya, Norway & 380 & 69.28 & 16.01 & $\mathrm{~N}$ \\
\hline Athens, Greece & 200 & 37.96 & 23.78 & SE \\
\hline Barcelona, Spain & 115 & 41.39 & 2.11 & SW \\
\hline Belsk, Poland & 180 & 51.84 & 20.79 & $\mathrm{~N}$ \\
\hline Bucharest-Măgurele, Romania & 93 & 44.45 & 26.03 & SE \\
\hline Cabauw, the Netherlands & 1 & 51.97 & 4.93 & $\mathrm{~N}$ \\
\hline Évora, Portugal & 293 & 38.57 & -7.91 & SW \\
\hline Garmisch-Partenkirchen, Germany & 730 & 47.48 & 11.06 & $\mathrm{C}$ \\
\hline Granada, Spain & 680 & 37.16 & -3.61 & SW \\
\hline Hamburg, Germany & 25 & 53.57 & 9.97 & $\mathrm{~N}$ \\
\hline Ispra, Italy & 209 & 45.82 & 8.63 & $\mathrm{C}$ \\
\hline L'Aquila, Italy & 683 & 42.38 & 13.32 & SE \\
\hline Lecce, Italy & 30 & 40.30 & 18.10 & SE \\
\hline Leipzig, Germany & 100 & 51.35 & 12.44 & $\mathrm{~N}$ \\
\hline Linköping, Sweden & 80 & 58.39 & 15.57 & $\mathrm{~N}$ \\
\hline Madrid, Spain & 669 & 40.45 & -3.73 & SW \\
\hline Maisach, Germany & 515 & 48.21 & 11.26 & $\mathrm{C}$ \\
\hline Minsk, Belarus & 200 & 53.92 & 27.60 & $\mathrm{~N}$ \\
\hline Naples, Italy & 118 & 40.84 & 14.18 & SE \\
\hline Neuchâtel, Switzerland & 487 & 47.00 & 6.96 & $\mathrm{C}$ \\
\hline OHP, France & 683 & 43.96 & 5.71 & SW \\
\hline Palaiseau, France & 162 & 48.70 & 2.20 & $\mathrm{~N}$ \\
\hline Payerne, Switzerland & 456 & 46.81 & 6.94 & $\mathrm{C}$ \\
\hline Potenza, Italy & 760 & 40.60 & 15.72 & SE \\
\hline Sofia, Bulgaria & 550 & 42.67 & 23.33 & SE \\
\hline Thessaloniki, Greece & 60 & 40.63 & 22.95 & SE \\
\hline
\end{tabular}

when volcanic ash was detected and satellite data were available. Since the satellite AOD estimates were given at $550 \mathrm{~nm}$ we considered scaling the lidar-determined ash layer optical depth to $550 \mathrm{~nm}$ using an appropriate Ångström exponent. According to Pappalardo et al. (2013) and based on EARLINET observations, the Ångström exponent between 355 and $532 \mathrm{~nm}$ ranges between 0.03 and -0.11 . Thus we used an exponent equal to zero, which practically means that the optical depths to be compared were not scaled.

\subsection{Comparison methodology}

\subsubsection{Methodology for the EARLINET-satellite comparisons}

The values of each satellite product have been restricted to an area of variable radius around each EARLINET station, depending on the satellite. The closest measurement in space and time has been selected for each overpass, within the limits set by the collocation criteria shown in Table 2 . This was compared to the respective layer characterized by EARLINET as volcanic particles. First the spatial collocation criteria have been applied to satellite data and then the temporal ones. The EARLINET relational database for this event con- tains cases for which two or more volcanic layers are simultaneously observed in the atmospheric column. For these cases the worst correlated layer to the satellite data was excluded from analysis. A summary of the satellite data compared with the EARLINET measurements and the corresponding collocation criteria can be found in Table 2. For all the satellite products a comparison of the AOD has taken place. For the satellite products that provided volcanic ash layer height information, a comparison of volcanic ash layer height was also performed. The AOD of the EARLINET layers was derived by the layers' integrated backscatter coefficient multiplied by a fixed extinction-to-backscatter ratio with a value of $50 \mathrm{sr}^{-1}$ (Ansmann et al., 2010). We did not use any Raman lidar measurements since most comparisons were performed for daytime conditions. An estimated $20 \%$ uncertainty on the EARLINET AOD was applied due to the variability in the lidar ratio for volcanic particles, typically between 40 and $60 \mathrm{sr}^{-1}$ (see Pappalardo et al., 2013, and references therein). For the layer height comparison, the height of the centre of mass provided by the EARLINET database was used, and as estimated layer depth, the distance between the mass centre from the layer top and base was employed. All the satellite ash optical depth products were calculated at $550 \mathrm{~nm}$, apart 
Table 2. Collocation criteria examined in the EARLINET-satellite comparisons.

\begin{tabular}{|c|c|c|c|c|c|c|}
\hline Institute & Satellite product & $\begin{array}{l}\text { Overpass } \\
\text { time }\end{array}$ & $\begin{array}{l}\text { Amount of } \\
\text { data in days }\end{array}$ & $\begin{array}{l}\text { Collocation } \\
\text { criteria }\end{array}$ & $\begin{array}{l}\text { Number of } \\
\text { coincidences }\end{array}$ & Comments \\
\hline KNMI & GOME-2/MetOp-A & 09:30 LT & 14 & $3 \mathrm{~h}$ and $300 \mathrm{~km}$ & 12 & \\
\hline UOXF & $\begin{array}{l}\text { IASI/MetOp-A } \\
\text { nominal algorithm }\end{array}$ & $\begin{array}{l}\text { 09:30 LT } \\
\text { 21:30 LT }\end{array}$ & 18 & $1 \mathrm{~h}$ and $100 \mathrm{~km}$ & 18 & \\
\hline UOXF & $\begin{array}{l}\text { IASI/MetOp-A } \\
\text { fast algorithm }\end{array}$ & $\begin{array}{l}\text { 09:30 LT } \\
21: 30 \mathrm{LT}\end{array}$ & 19 & $1 \mathrm{~h}$ and $100 \mathrm{~km}$ & 20 & $\begin{array}{l}3 \text { fixed heights provided, } \\
400,600 \text { and } 800 \mathrm{hPa}\end{array}$ \\
\hline ULB & IASI/MetOp-A & $\begin{array}{l}\text { 09:30 LT } \\
\text { 21:30 LT }\end{array}$ & 48 & $1 \mathrm{~h}$ and $100 \mathrm{~km}$ & 13 & \\
\hline
\end{tabular}

from the KNMI/GOME-2 products, which were calculated first at $380 \mathrm{~nm}$ and then scaled to $550 \mathrm{~nm}$ using appropriate Ångström exponents provided by the satellite team. In order to convert the infrared optical depth to optical depth at $550 \mathrm{~nm}$, both ULB and UOXF teams used the Eyja refractive indices from Dan Peters (private communication), with a value of $1.572+i 7.5 \times 10^{-6}$ at $530 \mathrm{~nm}$. Correspondingly, $532 \mathrm{~nm}$ lidar measurements were used in the comparisons.

\subsubsection{Methodology for the aircraft-satellite comparisons}

The airborne lidar data were available on a per flight basis (Koukouli et al., 2014b) and included aerosol extinction profiles that provided ash plume height and ash layer optical depth. The values of these variables were compared with the satellite produced values of ash optical depth and aerosol layer height (where given) examining different collocation criteria corresponding to an area of a radius ranging from 50 to $200 \mathrm{~km}$ (see Table 3). The closest satellite value, within the selected spatial criteria, for every flight path location was found and used for the comparisons. Since the overpass times of the satellite data are around 09:30 and 21:30 LT, in order to allow for collocation, only spatial criteria where used. None of the available aircraft data were available within 1$2 \mathrm{~h}$ of the overpass time, which was the criterion that provided the best matches when using the EARLINET data. The time difference between satellite and aircraft data was around $5 \mathrm{~h}$. This fact does not allow a point-to-point comparison of the measurements but the comparisons will mainly highlight whether the ash products from the two measuring systems are consistent. A summary of the satellite data compared against the flight measurements and the corresponding collocation criteria can be found in Table 3 .

\section{Results and discussion}

\subsection{Comparison of ash optical depth and ash layer height with EARLINET data}

As shown in Table 3, we applied different collocation criteria between the EARLINET lidar measurements and the satellite observations in order to investigate which one provides the best results and a reasonable number of matches. Although the EARLINET stations performed a large number of dedicated intensive measurements during April and May 2010, the overpass time of the MetOp-A satellite significantly limited the number of collocations. We examined, for each of the collocation criteria, the correlation coefficient between the lidar-determined optical depth of the pure volcanic particles layer and the corresponding satellite estimate. Furthermore, we examined the correlation coefficient between the ash layer height estimated from the lidar measurements and the one retrieved from the satellite algorithms when available (Koukouli et al., 2014b). In Fig. 2 we present scatter plots between EARLINET ash layer optical depth and each satellite ash product for those collocation criteria that showed the largest correlation. The best correlations were found when limiting the matches to within a radius of $100 \mathrm{~km}$ from the ground-based lidar and considering measurements with a $1 \mathrm{~h}$ difference. When deviating from these criteria, the number of matches increased but the correlation declined. This fact provides an indication of the spatial and temporal representativeness of single lidar profiles. Different colours in these plots correspond to different European regions (see Table 1) in order to examine whether the distance from the source and the transport path have an impact on the comparisons.

The GOME-2A comparisons are shown in Fig. $2 a$ and $b$ with the "DUST" refractive index in the left column and the "VOLZ" refractive index in the right column. Only 12 collocations were found for the GOME-2 and the EARLINET observations. There is a small correlation between the data sets, ranging between 0.33 and 0.46 for the "DUST" and "VOLZ" products respectively. This limited number of collocations was given by a radius of $300 \mathrm{~km}$ from each ground-based station and within $5 \mathrm{~h}$. The GOME-2A estimates of the ash layer optical depth are systematically larger than the lidar ones and most of them are larger than 1, although for these cases the lidar data rarely exceed the value 0.5 . The large GOME-2 pixel size $(80 \mathrm{~km} \times 40 \mathrm{~km})$ and the large search radius $(300 \mathrm{~km})$ could partly explain differences with point measurements, like the lidar; however, it seems possible that, despite the screening of the cloudy events, contamination could still be 
Table 3. Collocation criteria examined in the aircraft-satellite comparisons. The flights were performed between 13:00 and 17:30 UTC.

\begin{tabular}{|c|c|c|c|c|c|c|}
\hline Institute & Satellite product & $\begin{array}{l}\text { Overpass } \\
\text { time }\end{array}$ & $\begin{array}{l}\text { Number of } \\
\text { data in days }\end{array}$ & $\begin{array}{l}\text { Collocation } \\
\text { criteria }\end{array}$ & $\begin{array}{l}\text { Number of } \\
\text { coincidences }\end{array}$ & Comments \\
\hline & & & Max 5 & No time constraint & & \\
\hline KNMI & GOME-2/MetOp-A & 09:30 LT & 1 & $100 / 200 \mathrm{~km}$ & 64 & \\
\hline UOXF & $\begin{array}{l}\text { IASI/MetOp-A } \\
\text { nominal algorithm }\end{array}$ & $\begin{array}{l}\text { 09:30 LT } \\
21: 30 \mathrm{LT}\end{array}$ & 4 & $50 / 100 / 200 \mathrm{~km}$ & 787 & \\
\hline UOXF & $\begin{array}{l}\text { IASI/MetOp-A } \\
\text { fast algorithm }\end{array}$ & $\begin{array}{l}09: 30 \mathrm{LT} \\
21: 30 \mathrm{LT}\end{array}$ & 4 & $50 / 100 / 200 \mathrm{~km}$ & $732-776$ & $\begin{array}{l}3 \text { fixed heights provided, } \\
400,600 \text { and } 800 \text { mbar }\end{array}$ \\
\hline ULB & IASI/MetOp-A & $\begin{array}{l}09: 30 \mathrm{LT} \\
21: 30 \mathrm{LT}\end{array}$ & 5 & $50 / 100 / 200 \mathrm{~km}$ & 463 & \\
\hline
\end{tabular}

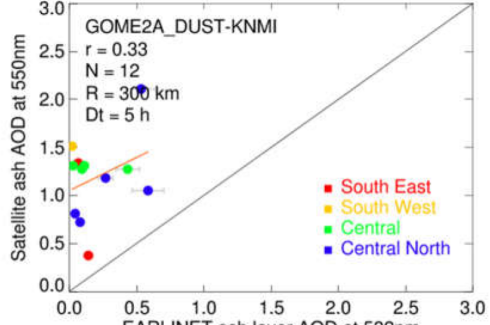

(a)

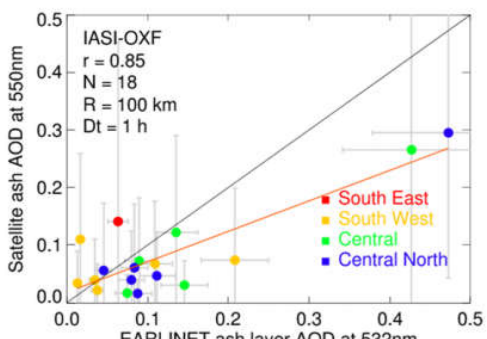

(c)

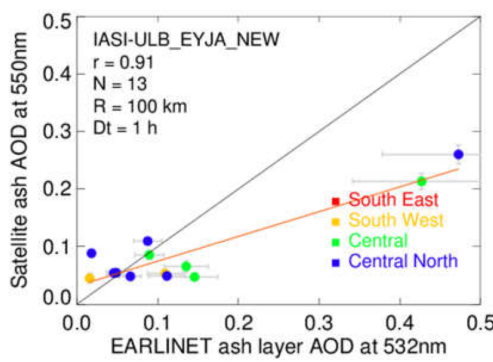

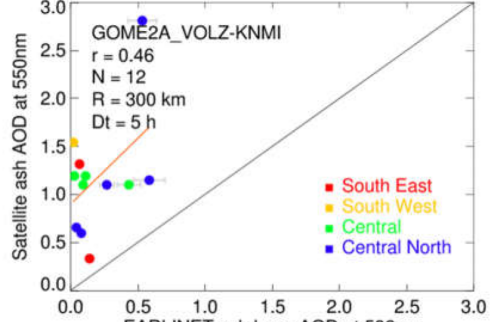

(b)

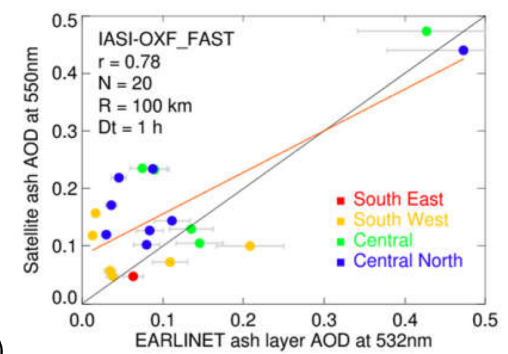

(d)

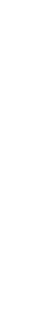

Figure 2. Scatter plots between satellite ash optical depth at $550 \mathrm{~nm}$ and EARLINET ash layer optical depth at 532 nm for GOME-2A (a, b), IASI-UOXF (c, d) and IASI-ULB (e) products. Different colours correspond to different European domains. See Table 1 for more details.

possible from thin clouds in the GOME-2A retrievals, considering the pixel size, which is compared to the point lidar measurement. The lidar data included in the EARLINET database have been thoroughly cloud-screened. Between the two GOME-2A products the "VOLZ" algorithm shows a slightly better correlation coefficient with the ground-based lidars.

The scatter plots of UOXF ash optical depth and collocated EARLINET measurements are presented in Fig. $2 \mathrm{c}$ and d; the plot in the left column corresponds to the iterative algorithm and the right column corresponds to the "fast" algorithm at a fixed height of $600 \mathrm{hPa}$, which is consistent with the average height where EARLINET observed volcanic particles. For both algorithms the collocation criteria that provided the best results were a distance from each ground-based station of $100 \mathrm{~km}$ and a maximum time difference of $1 \mathrm{~h}$. These criteria allowed for almost 20 coincidences. As it can be quickly verified by the results shown in Fig. $2 c$ and d, the ash AOD 
Table 4. Statistical mean values and associated standard deviation for the EARLINET and the satellite ash optical depth estimates presented for collocated measurements.

\begin{tabular}{|c|c|c|c|c|c|c|c|c|}
\hline Product & $\begin{array}{l}\text { Spatio-temporal } \\
\text { criteria }\end{array}$ & $\begin{array}{r}\text { Satellite mean } \\
\text { AOD at } 550 \mathrm{~nm}\end{array}$ & $\begin{array}{l}\text { EARLINET mean } \\
\text { AOD at } 532 \mathrm{~nm}\end{array}$ & $\begin{array}{r}\text { Bias } \\
(\text { SAT-GB })\end{array}$ & $\begin{array}{r}\text { rms } \\
\text { difference }\end{array}$ & $r$ & Slope & Intercept \\
\hline GOME-2A, KNMI DUST & $300 \mathrm{~km}$ and $5 \mathrm{~h}$ & $1.18 \pm 0.43$ & $0.19 \pm 0.21$ & 0.98 & 0.41 & 0.33 & 0.69 & 1.05 \\
\hline GOME-2A. KNMI VOLZ & $300 \mathrm{~km}$ and $5 \mathrm{~h}$ & $1.17 \pm 0.61$ & $0.19 \pm 0.21$ & 0.97 & 0.55 & 0.46 & 1.37 & 0.90 \\
\hline IASI, UOXF nominal & $100 \mathrm{~km}$ and $1 \mathrm{~h}$ & $0.08 \pm 0.08$ & $0.12 \pm 0.12$ & -0.04 & 0.07 & 0.85 & 0.53 & 0.02 \\
\hline IASI, UOXF fast $400 \mathrm{hPa}$ & $100 \mathrm{~km}$ and $1 \mathrm{~h}$ & $0.10 \pm 0.04$ & $0.12 \pm 0.12$ & -0.01 & 0.1 & 0.70 & 0.21 & 0.07 \\
\hline IASI, UOXF fast $600 \mathrm{hPa}$ & $100 \mathrm{~km}$ and $1 \mathrm{~h}$ & $0.17 \pm 0.12$ & $0.12 \pm 0.12$ & 0.05 & 0.08 & 0.78 & 0.72 & 0.08 \\
\hline IASI, UOXF fast $800 \mathrm{hPa}$ & $100 \mathrm{~km}$ and $1 \mathrm{~h}$ & $0.32 \pm 0.38$ & $0.12 \pm 0.12$ & 0.20 & 0.28 & 0.78 & 2.62 & 0.02 \\
\hline IASI, ULB & $100 \mathrm{~km}$ and $1 \mathrm{~h}$ & $0.09 \pm 0.07$ & $0.14 \pm 0.14$ & -0.04 & 0.08 & 0.91 & 0.43 & 0.03 \\
\hline
\end{tabular}

extracted from the IASI/MetOp-A Oxford iterative algorithm is quite low, with values rarely rising above 0.2 , which is consistent with the EARLINET measurements, which show similar AOD levels. There are only two cases showing AOD values larger than 0.2 , and these are also consistent with EARLINET, since the lidar data for these two cases show significantly larger values, above 0.4 . The correlation coefficient is quite promising at 0.85 ; however, it is based on only 18 coincident measurements. The agreement between IASI and EARLINET estimates is similar for the "fast" algorithm, showing a larger scatter for the low AOD values but potentially less scatter for larger AODs. This larger scatter leads to a smaller correlation coefficient close to 0.78 . If we loosen the collocation criteria to $300 \mathrm{~km}$ and $3 \mathrm{~h}$ then the correlation coefficient drops significantly to a value of less than 0.5.

In Fig. 2e we show comparisons of the ash optical depth from the ULB algorithm with EARLINET estimates. The results are shown for the same collocation criteria applied to UOXF comparisons, i.e. $100 \mathrm{~km}$ distance and $1 \mathrm{~h}$ difference between the observations. The general picture is consistent with the IASI/UOXF data sets; however, the number of coincidences decreases to only 13 , since the two algorithms have different criteria for considering a retrieval as successful. The comparisons show a correlation of 0.91 , which is the largest found in all comparisons shown in Fig. 2, based, however, on a small number of measurements. Table 4 provides the mean EARLINET and satellite ash optical depths for the coincidences shown in Fig. 2, along with the mean bias, the rms of the differences, the correlation coefficient and the slope and intercept of the regression line. The average AOD values of the measurements that meet the collocation criteria are small (less than 0.2) and consistent with each other, showing a small mean bias, except in the case of GOME-2A and when the IASI-UOXF fast algorithm has a fixed height of $800 \mathrm{hPa}$ (not shown in Fig. 2), where the satellite data significantly overestimate the ash optical depth. However, as is demonstrated in the rms differences, the scatter is quite large and, even when the correlation coefficients are good, the slope of the regression line is not close to 1 . Concerning the IASI retrievals, all data sets tend to slightly overestimate the small AOD values and underestimate the high AOD values, while those of GOME-2, as stated, show a systematic overestimation. We need to reiterate, however, that all the statistics are based on a small number of coincidences.

The GOME-2A ash products and the iterative IASI product processed by UOXF provided the height of the ash layer. These heights were compared with the estimates from EARLINET and the results are shown in Fig. 3. The ash plume heights estimated for GOME-2A products and the EARLINET network are compared in Fig. 3a. Irrespective of the product and the search radius (not shown here) the comparison is not satisfactory for either of the two algorithms. The GOME-2A-provided height seems to strongly underestimate the ground-based values, showing a narrower range of values between 1 and $5 \mathrm{~km}$. The ground instruments show a more physical spread of the ash cloud locating it between 2 and $6 \mathrm{~km}$. The comparison of the ash plume height extracted from the IASI/MetOp-A UOXF iterative algorithm and the one observed by the EARLINET network is shown in Fig. 3b. It is evident from this figure that the spread of plume heights found by the EARLINET network is higher than those found by the Oxford iterative IASI algorithm, leading to rather poor correlations. The estimate of the mean is consistent between the data sets. This fact is demonstrated in the summary table (Table 5), which gives the mean EARLINET and satellite ash plume height estimates. The large scatter bars indicate the variability inherent in both sets of observations. We have to note here that the UOXF fast algorithm with fixed heights for the ash performs better for $600 \mathrm{hPa}$, which is consistent with the average heights estimated by the nominal algorithm and the EARLINET data, which range between 3 and $4 \mathrm{~km}$. In all lidar-satellite comparisons there was no indication that there were regions where the agreement between the two data sets is better, due to their proximity to the source. However, this conclusion is based, especially for certain regions, on extremely few data.

\subsection{Comparisons of ash optical depth and ash layer height with airborne lidar data}

During May 2010 there were 12 flights of the UK's BAe-146301 Atmospheric Research Aircraft (Marenco et al., 2011), and during six of these volcanic ash was detected in the air- 
Table 5. Statistical mean values and associated standard deviation (SD) for the EARLINET and the satellite ash plume height estimates.

\begin{tabular}{llrrrr}
\hline Product & $\begin{array}{l}\text { Spatio-temporal } \\
\text { criteria }\end{array}$ & $\begin{array}{r}\text { Satellite mean } \\
\text { and SD }(\mathrm{km})\end{array}$ & $\begin{array}{r}\text { EARLINET mean } \\
\text { and SD }(\mathrm{km})\end{array}$ & $\begin{array}{r}\text { Mean bias (SAT-GB) } \\
\text { in km }\end{array}$ & $\begin{array}{r}\text { rms difference } \\
\text { in km }\end{array}$ \\
\hline IASI, UOXF nominal & 100 km and 1 h & $3.4 \pm 0.78$ & $3.63 \pm 0.95$ & -0.22 & 1.39 \\
GOME-2/MetOp-A & 300 km and 5 h & $2.07 \pm 1.22$ & $3.92 \pm 1.22$ & -1.84 & 2.18 \\
\hline
\end{tabular}

(a)
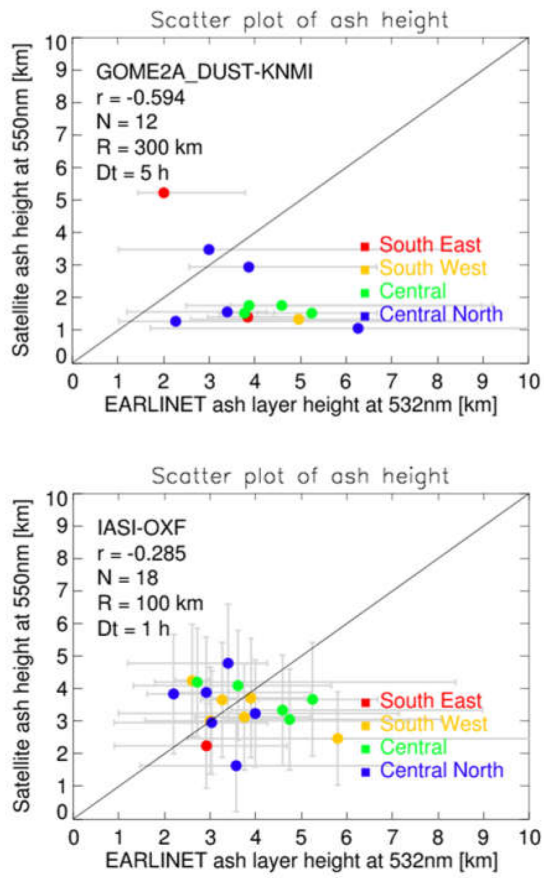

Figure 3. Scatter plots between satellite ash layer height and EARLINET ash layer height (in $\mathrm{km}$ ) for GOME-2A (a) and IASIUOXF (b).

borne lidar measurements. In order to avoid contamination from cirrus clouds and mixed aerosol layers, we only show comparisons with the satellite data for two flights, during which significant levels of pure ash, not mixed with other aerosol types, were observed by the airborne lidar measurements. The flight that took place on 16 May 2010 (see also Fig. 1) started at 12:55 UTC and ended at 18:00 UTC, and the aircraft mostly flew over Scotland and northern England. During this flight most of the ash was observed between 55 and $56^{\circ} \mathrm{N}$. The flight that took place on 17 May over the Irish and North Sea started a little earlier at 11:15 UTC and ended at 16:58 UTC, and most of the ash was observed over the North Sea between 1 and $2^{\circ} \mathrm{E}$. As is demonstrated in Table 3, we only used spatial criteria to find coincidences between the airborne lidar data and the satellite data of the same day, since both flights were performed in the afternoon, while the satellite overpasses are close to 09:30 LT (GOME-2A and IASI) and 21:30LT (IASI only). For GOME-2 we found coincidences only for 17 May 2010. The airborne lidar data give a time series of data for each measurement day. As data are not truly coincident with the satellite data (the overpass time being early in the morning and late in the evening, whereas flights were near the middle of the day), volcanic plumes have undergone advection between the measurements compared. Looking at the data as a time series it makes it easier to capture differences due to the misplacement of plumes. Therefore we do not show correlation coefficients and scatter plots for the satellite-aircraft comparisons, because these are not truly coincident and thus the estimated statistics did not show a good correlation. This could, however, be misleading concerning the usefulness of the comparisons and therefore we decided to show and discuss only qualitatively about the spatial consistency between the aircraft and the satellite data.

In Fig. 4 we show the comparisons of the satellite ash optical depth and the airborne lidar ash layer optical depth for $550 \mathrm{~nm}$ as a function of aircraft time (closest point in space). In Fig. 4e and $\mathrm{f}$ we also show the flight track for the two flights examined. The actual flight time is indicated on the path in order to be able to identify the spatial location that corresponds to the footprint of the lidar data. Since the time difference between the flight measurement and the satellite overpass is large what we would actually see from the comparisons is (a) whether the aircraft and the satellite observe the plume over the same area and (b) whether they observe similar optical depth values. This would occur if the dispersion, or transport, of the plume was not significant during the hours elapsing between the satellite overpass and the aircraft measurement, within the spatial criteria we applied for the comparisons. In Fig. $4 \mathrm{a}$ and $\mathrm{b}$ we show the comparisons between IASI ash optical depth for the iterative and fast algorithm of UOXF vs. the ash layer optical depth from the airborne lidar measurements for 16 May 2010, where the measurements are shown as a function of time in UTC. In Fig. $4 \mathrm{e}$ and $\mathrm{f}$, we plot the flight path for the two days (16 and 17 May 2010). Along the path the flight time in UTC is posted, while the different colours along the flight path indicate the ash optical depth. As we can see, the satellite data processed with the iterative UOXF algorithm capture the high AODs observed around 14:00 UTC and between 16:00 and 17:00 UTC quite well, which is not the case with the peak observed between 15:00 and 16:00 UTC. Such discrepancies can be expected, considering the time difference between the airborne data and the satellite measurements. In addition, it seems that the background is similar but that some larger values are observed between the ash peaks. The situ- 
(a)
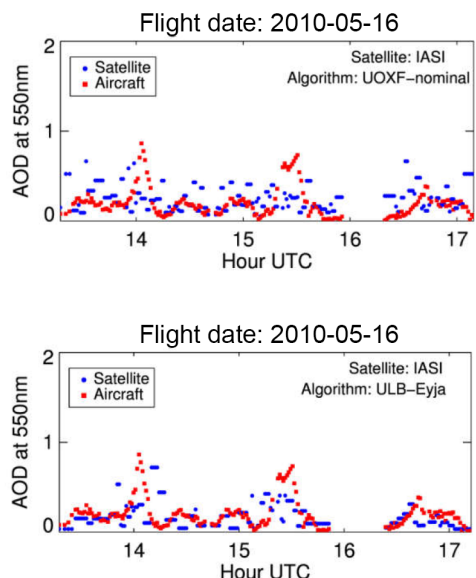

(c)

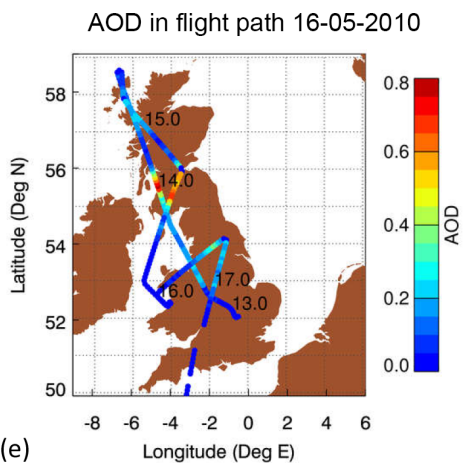

(b)
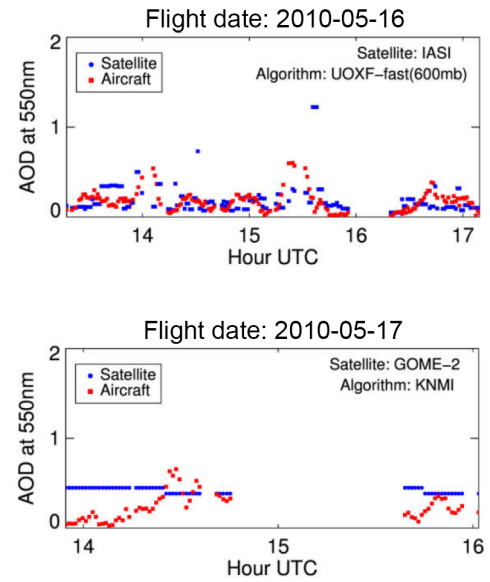

(d)

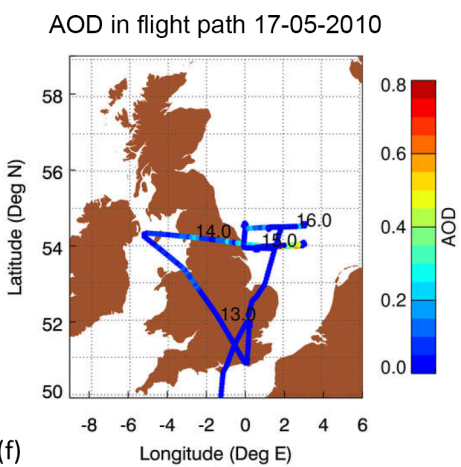

Figure 4. Ash optical depth at $550 \mathrm{~nm}$ and airborne lidar ash layer optical depth at $355 \mathrm{~nm}$ as a function of aircraft time. IASI-UOXF products for 16 May 2010 (a, b), IASI-ULB products for 16 May 2010 (c) and GOME-2A product for 17 May 2010 (d). The flight tracks for these two days, coloured according to AOD, are shown in panels (e) and (f).

ation is slightly different when examining the comparisons between the aircraft data and the estimates from the UOXF fast algorithm using a fixed height of the ash layer at $600 \mathrm{hPa}$. In general, the UOXF fast algorithm estimates smaller values (including the background); it captures the peak observed around 14:00 UTC well and overestimates the peak in AOD observed between 15:00 and 16:00 UTC, and it is hard to tell whether the smaller peak observed around 17:00 UTC is well depicted or not.

In Fig. 4c, we present the comparisons between the aircraft data and the estimates from the ULB Eyja algorithm again for 16 May 2010. The satellite estimates follow all peaks observed in the aircraft data quite well, although slightly misplaced. Checking the SEVIRI ash imagery at http://fred.nilu.no for 16 May 2010 we observe an almost constant west-east flow of dust throughout the day between 55 and $58^{\circ} \mathrm{N}$, and thus this plume was captured by both the morning and the evening orbit of IASI, as well as by the aircraft when flying over these latitudes between 14:00 and 16:00 UTC. SEVIRI observed a plume after 17:00 UTC south of $54^{\circ} \mathrm{N}$ moving south-east. The early evolution of this plume was captured by the aircraft around 17:00 UTC, and its later evolution was captured over the same area by the evening orbit of IASI. This plume evolution can partly explain the displacement observed, since the satellite data are not coincident in time with the aircraft data and the time in $x$ axis of the plots actually corresponds to different latitude/longitude of the comparisons.

In Fig. $4 d$ we present the corresponding comparisons between the aircraft data and the estimates from the GOME-2 KNMI algorithm for 17 May 2010, and in Fig. 4f the corresponding flight path of the aircraft. The GOME-2 results capture the levels of the two AOD peaks observed in the aircraft measurements but fail to capture small-scale variability in the AOD and the background levels. On 17 May the aircraft mainly flew an east-west track (whereas on 16 May it was mainly a north-south track), the comparison is coarser and the same satellite data point is assigned to several airborne measurements, resulting in the horizontal lines in Figure $4 \mathrm{~d}$. In these cases we actually compare only the morning orbit (09:30 UTC) since GOME-2 is a UV-visible sensor. SEVIRI images show a south-east movement of the ash plume starting east of the coast of England and going towards the Netherlands. The east-west motion of the aircraft over 
Table 6. Statistical mean values and associated standard deviation for the airborne lidar and the satellite ash optical depth estimates at $550 \mathrm{~nm}$ presented for collocated measurements.

\begin{tabular}{lllrrrr}
\hline Institute & $\begin{array}{l}\text { Instrument and } \\
\text { algorithm }\end{array}$ & $\begin{array}{r}\text { Spatial } \\
\text { criteria }\end{array}$ & $\begin{array}{r}\text { Mean satellite } \\
\text { AOD levels }\end{array}$ & $\begin{array}{r}\text { Mean aircraft } \\
\text { AOD Levels }\end{array}$ & $\begin{array}{r}\text { Bias } \\
\text { (SAT-AIR) }\end{array}$ & $\begin{array}{r}\text { rms } \\
\text { difference }\end{array}$ \\
\hline KNMI & GOME-2/MetOp-A & $200 \mathrm{~km}$ & $0.42 \pm 0.03$ & $0.23 \pm 0.15$ & 0.19 & 0.26 \\
UOXF & IASI/MetOp-A nominal algorithm & $50 \mathrm{~km}$ & $0.28 \pm 0.25$ & $0.19 \pm 0.16$ & 0.09 & 0.28 \\
UOXF & IASI/MetOp-A fast algorithm $400 \mathrm{hPa}$ & $50 \mathrm{~km}$ & $0.20 \pm 0.30$ & $0.19 \pm 0.16$ & 0.01 & 0.29 \\
UOXF & IASI/MetOp-A fast algorithm $600 \mathrm{hPa}$ & $50 \mathrm{~km}$ & $0.23 \pm 0.29$ & $0.18 \pm 0.15$ & 0.05 & 0.26 \\
UOXF & IASI/MetOp-A fast algorithm $800 \mathrm{hPa}$ & $50 \mathrm{~km}$ & $0.30 \pm 0.40$ & $0.18 \pm 0.16$ & 0.11 & 0.37 \\
ULB & IASI/MetOp-A & $50 \mathrm{~km}$ & $0.21 \pm 0.15$ & $0.25 \pm 0.17$ & -0.04 & 0.23 \\
\hline
\end{tabular}

the sea captured this plume between 14:30 and 15:00 UTC, and GOME-2 observed this plume over the same area in the morning. Before 14:30 UTC the aircraft was flying over land and did not observe any significant ash, so when compared with the morning observations of GOME-2 and considering the pixel size of GOME-2 and the collocation criteria applied, these measurements are actually compared with satellite data over the sea. Considering the large time difference between the flight and GOME-2 overpass and the much larger pixel size of GOME-2, compared to IASI, it is remarkable that the satellite data can quantitatively capture the ash optical depth in the greater flight area. Table 6 summarizes the mean AOD values observed from the aircraft lidar and each of the satellite products examined.

Finally, in Fig. 5 we present the comparisons of the ash layer height observed from the aircraft measurements and the corresponding effective ash height estimated from the UOXF-iterative algorithm based on IASI (Fig. 5a) and the KNMI algorithm based on GOME-2 (Fig. 5b). Considering the constraints induced by the collocation criteria, both algorithms show very good agreement with the corresponding heights estimated from the airborne lidar data in most of the collocations, with the ash height mainly ranging between 3 and $5 \mathrm{~km}$. Table 7 summarizes the mean ash layer height observed from the aircraft measurements and each satellite product examined.

\section{Summary and conclusions}

The main aim of this work is to present a first attempt to validate improved and dedicated satellite-derived ash plume level assessments as part of the European Space Agency initiatives, in order to create an optimal "end-to-end system for volcanic ash plume monitoring and prediction systems". The data used as reference for the validation were not part of a specifically designed validation campaign, which explains the small number of coincident data found. The results shown are complementary to other satellite volcanic ash products, e.g. from SEVIRI (Prata and Prata, 2012; Clarisse and Prata, 2016; WMO, 2015). Different AOD and ash plume height estimations from GOME2/MetOp-A and IASI/MetOp-A have
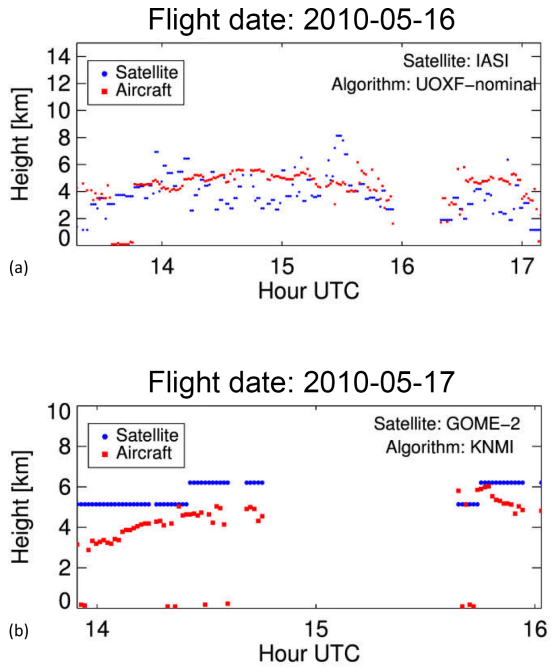

Figure 5. Ash layer height and aircraft lidar ash layer height (in $\mathrm{km})$ at $355 \mathrm{~nm}$ as a function of aircraft time: GOME-2A for 17 May 2010 (a) and IASI-UOXF for 16 May 2010 (b).

been assessed against collocated ground-based and airborne lidar data for the 2010 eruptions of the Icelandic volcano Eyjafjallajökull. The GOME2/MetOp-A measurements have been analysed by the Royal Netherlands Meteorological Institute (KNMI) and the IASI/MetOp-A observations by both the Université Libre de Bruxelles (ULB) and the University of Oxford (UOXF). Different algorithm versions and parameters were examined and inter-compared. Both aerosol optical depth and ash plume height satellite estimates were compared with European Aerosol Research Lidar Network (EARLINET) lidar measurements and the UK's BAe-146301 Atmospheric Research Aircraft flying over the UK during the eruptive period.

- The KNMI GOME2 AOD overestimates the groundbased values, showing quite high values for cases where the lidar sees a low AOD. As a result, the dust algorithm shows relatively low correlation coefficients of between 0.25 and 0.3 depending on the spatio-temporal search radius, whereas the VOLZ algorithms perform slightly better, with $r^{2}$ values ranging between 0.4 and 0.5 . 
Table 7. Statistical mean values and associated standard deviation (SD) for the airborne lidar and the satellite ash plume height estimates.

\begin{tabular}{lcrrrr}
\hline Product & $\begin{array}{r}\text { Spatial } \\
\text { criteria }\end{array}$ & $\begin{array}{r}\text { Satellite mean } \\
\text { and SD }(\mathrm{km})\end{array}$ & $\begin{array}{r}\text { Aircraft mean } \\
\text { and SD }(\mathrm{km})\end{array}$ & $\begin{array}{r}\text { Bias (SAT-AIR) } \\
\text { in km }\end{array}$ & $\begin{array}{r}\text { rms } \\
\text { difference }\end{array}$ \\
\hline IASI/MetOp-A, UOXF nominal & $50 \mathrm{~km}$ & $3.73 \pm 1.45$ & $4.30 \pm 2.00$ & -0.59 & 2.29 \\
GOME-2/MetOp-A, KNMI & $200 \mathrm{~km}$ & $5.62 \pm 0.54$ & $3.87 \pm 1.70$ & 1.75 & 2.33 \\
\hline
\end{tabular}

The KNMI/GOME2 data seem to suffer from the spatial resolution of the satellite instrument, which made the spatial criterion somewhat too large, hence precluding any conclusive comparisons when compared to the aircraft measurements. The agreement between the satellite-derived and airborne lidar effective ash heights differ only by $1 \mathrm{~km}$ on the average, indicating a homogenous spread of the plume under the satellite's pixel. The KNMI GOME2 ash plume height comparisons are not satisfactory, irrespective of the search radius, for either of the two algorithms. The satellite ash height values seem to underestimate the ground-based values, having a very narrow range of values between 1 and $2 \mathrm{~km}$ and a mean of $2.07 \pm 1.22 \mathrm{~km}$. In comparisons, the ground instruments show a more natural spread between 3 and $6 \mathrm{~km}$ with a mean of $3.92 \pm 1.22 \mathrm{~km}$. It is highly likely that the large GOME-2 pixel size smooths out any small-scale variability in the plume height, which is otherwise captured by the ground-based single point measurements.

- The Oxford nominal IASI algorithm shows satisfactory AOD correlations against the ground AODs, with coefficients ranging between 0.6 and 0.85 , and, even though it provides rather small optical depths, these are of the same order of magnitude as the lidar. The algorithm presents quite good comparisons for the AOD patterns observed with aircraft lidar. The Oxford nominal IASI algorithm ash plume height comparisons do not show any significant correlation with the EARLINET estimates. The satellite estimates have no spread in values compared to the lidar estimates; however, both data sets show similar average values, indicating that the satellite estimates can capture the average conditions. The results are better when compared with the aircraft lidar, where it seems that the satellite estimates follow the variability in ash height along the flight route; however, they slightly underestimate the height values with a mean of $3.73 \pm 1.45 \mathrm{~km}$ (compared to the aircraft mean of $4.30 \pm 2.00 \mathrm{~km})$.

- The Oxford fast IASI algorithm also provides AOD estimates of the same order of magnitude as the ground lidar, with the narrower spatio-temporal choice providing the most promising results: the $400 \mathrm{hPa}$ product has a correlation of around 0.7 and the $800 \mathrm{hPa}$ product a correlation of around 0.8 . The Oxford fast IASI algo- rithm shows a very good agreement with the aircraft lidar, where the $600 \mathrm{hPa}$ product, which corresponds to the actual plume height, appears to perform best.

- The ULB AOD estimates are the most promising, showing the highest correlation coefficients, ranging between 0.74 and 0.91 , depending on the spatio-temporal criterion chosen. This is also valid when we examine the ULB IASI-aircraft comparisons. The ULB IASI algorithm shows a very good agreement, both with respect to the absolute AOD values and the AOD features during the flight shown. The actual absolute AOD maxima are also represented best by this product.

Concluding, we note that, depending on the careful choice of collocation criteria, the satellite algorithms investigated here can observe the ash optical depth and plume height for large enough eruptions to a satisfactory degree. The results shown in this study are in line with the main finding of the dedicated WMO intercomparison study (2015) concerning the agreement between satellite ash products and validation data sets (for AOD correlations between 0.4 and 0.6 and ash layer height agreement within $2 \mathrm{~km}$ ), and in some cases the results shown here show better statistics. However, in order to quantify the levels of accuracy of the satellite assessments, eruptions with strong ash plumes need to be included in this type of validation exercise, since there were too few collocation scenes for most satellite products for the Eyjafjallajökull and Grímsvötn 2010 and 2011 eruptions, as examined in the course of the SACS/SMASH ESA projects. This validation study highlights the need for dedicated validation campaigns during volcanic eruptions. For future eruptions it could be recommended to fly instrumented aircraft along the satellite orbit in order to optimize the collocations between satellite data and aircraft-based observations. It is recognized, however, that this would be a difficult campaign to plan, given that it is not possible to make long-term predictions of the eruptions.

\section{Data availability}

Lidar data of from the EARLINET network are freely available at http://www.earlinet.org. The airborne lidar data are available upon request from the UK Met Office. Satellite data of volcanic ash optical depth and layer height from GOME-2 and IASI instruments are available upon request by KNMI, ULB and UOXF. 
Acknowledgements. The comparison study was funded by the European Space Agency in the frame of the "Satellite Monitoring of Ash and Sulphur dioxide for the mitigation of Aviation Hazards" SACS-2 project. The financial support for EARLINET in the ACTRIS Research Infrastructure Project by the European Union's Horizon 2020 research and innovation programme under grant agreement no. 654169 and previously under grant agreement no. 262254 in the 7th Framework Programme (FP7/2007-2013) is gratefully acknowledged. The UK's BAe-146-301 Atmospheric Research Aircraft was flown by Directflight Ltd and managed by the Facility for Airborne Atmospheric Measurements (FAAM), which is a joint entity of the Natural Environment Research Council (NERC) and the Met Office. Lieven Clarisse is a research associate with the Belgian F.R.S.-FNRS. Lucy J. Ventress was funded through the NERC National Centre for Earth Observation. Roy G. Grainger and Elisa Carboni were supported by the NERC Centre for Observation and Modelling of Earthquakes, Volcanoes, and Tectonics (COMET).

Edited by: M. Tesche

\section{References}

Amiridis, V., Balis, D., Kazadzis, S., Bais, A., Giannakaki, E., Papayannis, A., and Zerefos, C.: Four years aerosol observations with a Raman lidar at Thessaloniki, Greece in the framework of EARLINET, J. Geophys. Res., 110, D21203, doi:10.1029/2005JD006190, 2005.

Amiridis, V., Balis, D. S., Giannakaki, E., Stohl, A., Kazadzis, S., Koukouli, M. E., and Zanis, P.: Optical characteristics of biomass burning aerosols over Southeastern Europe determined from UVRaman lidar measurements, Atmos. Chem. Phys., 9, 2431-2440, doi:10.5194/acp-9-2431-2009, 2009.

Ansmann, A., Boesenberg, J., Chaikovsky, A., Comeron, A., Eckhardt, S., Eixmann, R., Freudenthaler, V., Ginoux, P., Komguem, L., Linne, H., Lopez Marquez, M. A., Matthias, V., Mattis, I., Mitev, V., Mueller, D., Music, S., Nickovic, S., Pelon, J., Sauvage, L., Sobolewsky, P., Srivastava, M. K., Stohl, A., Torres, O., Vaughan, G., Wandinger, U., and Wiegner, M.: Long-range transport of Saharan dust to northern Europe: The 11-16 October 2001 outbreak with EARLINET, J. Geophys. Res., 108, 4783, doi:10.1029/2003JD003757, 2003.

Ansmann, A., Tesche, M., Groß, S., Freudenthaler, V., Seifert, P., Hiebsch, A., Schmidt, J., Wandinger, U., Mattis, I., Müller, D., and Wiegner, M.: The 16 April 2010 major volcanic ash plume over central Europe: EARLINET lidar and AERONET photometer observations at Leipzig and Munich, Germany, Geophys. Res. Lett., 37, L13810, doi:10.1029/2010GL043809, 2010.

Ansmann, A., Tesche, M., Seifert, P., Groß, S., Freudenthaler, V., Apituley, A., Wilson, K. M., Serikov, I., Linné, H., Heinold, B., Hiebsch, A., Schnell, F., Schmidt, J., Mattis, I., Wandinger, U., and Wiegner, M.: Ash and fine-mode particle mass profiles from EARLINET-AERONET observations over central Europe after the eruptions of the Eyjafjallajökull volcano in 2010, J. Geophys. Res., 116, D00U02, doi:10.1029/2010JD015567, 2011.

Böckmann, C., Wandinger, U., Ansmann, A., Bösenberg, J., Amiridis, V., Boselli, A., Delaval, A., De Tomasi, F., Frioud, M., Grigorov, I. V., Hågård, A., Horvat, M., Iarlori, M., Komguem,
L., Kreipl, S., Larchevêque, G., Matthias, V., Papayannis, A., Pappalardo, G., Rocadenbosch, F., Rodrigues, J. A., Schneider, J., Shcherbakov, V., and Wiegner, M.: Aerosol lidar intercomparison in the framework of EARLINET: Part II - Aerosol backscatter algorithms, Appl. Optics 43, 977-989, 2004.

Brenot, H., Theys, N., Clarisse, L., van Geffen, J., van Gent, J., Van Roozendael, M., van der A, R., Hurtmans, D., Coheur, P.-F., Clerbaux, C., Valks, P., Hedelt, P., Prata, F., Rasson, O., Sievers, K., and Zehner, C.: Support to Aviation Control Service (SACS): an online service for near-real-time satellite monitoring of volcanic plumes, Nat. Hazards Earth Syst. Sci., 14, 1099-1123, doi:10.5194/nhess-14-1099-2014, 2014.

Carboni, E., Grainger, R., Walker, J., Dudhia, A., and Siddans, R.: A new scheme for sulphur dioxide retrieval from IASI measurements: application to the Eyjafjallajökull eruption of April and May 2010, Atmos. Chem. Phys., 12, 11417-11434, doi:10.5194/acp-12-11417-2012, 2012.

Chazette, P., Dabas, A., Sanak, J., Lardier, M., and Royer, P.: French airborne lidar measurements for Eyjafjallajökull ash plume survey, Atmos. Chem. Phys., 12, 7059-7072, doi:10.5194/acp-127059-2012, 2012.

Christopher, S. A., Feng, N., Naeger, A., Johnson, B., and Marenco, F.: Satellite remote sensing analysis of the 2010 Eyjafjallajökull volcanic ash cloud over the North Sea during 4-18 May 2010, J. Geophys. Res., 117, D00U20, doi:10.1029/2011JD016850, 2012.

Clarisse, L. and Prata, F.: Infrared sounding of volcanic ash, in: Volcanic Ash: Methods of observation and monitoring, edited by: Mackie, S., Cashman, K., Rust, A., Ricketts, H., and Watson, I. M., in press, 2016.

Clarisse, L., Hurtmans, D., Prata, A. J., Karagulian, F., Clerbaux, C., Mazière, M. D., and Coheur, P.-F.: Retrieving radius, concentration, optical depth, and mass of different types of aerosols from high-resolution infrared nadir spectra, Appl. Optics, 49, 37133722, doi:10.1364/AO.49.003713, 2010.

Clarisse, L., Coheur, P.-F., Prata, F., Hadji-Lazaro, J., Hurtmans, D., and Clerbaux, C.: A unified approach to infrared aerosol remote sensing and type specification, Atmos. Chem. Phys., 13, 21952221, doi:10.5194/acp-13-2195-2013, 2013.

Clerbaux, C., Boynard, A., Clarisse, L., George, M., Hadji-Lazaro, J., Herbin, H., Hurtmans, D., Pommier, M., Razavi, A., Turquety, S., Wespes, C., and Coheur, P.-F.: Monitoring of atmospheric composition using the thermal infrared IASI/MetOp sounder, Atmos. Chem. Phys., 9, 6041-6054, doi:10.5194/acp-9-6041-2009, 2009.

de Graaf, M., Stammes, P., Torres, O., and Koelemeijer, R. B. A.: Absorbing Aerosol Index: Sensitivity analysis, application to GOME and comparison with TOMS, J. Geophys. Res., 110, D01201, doi:10.1029/2004JD005178, 2005.

EARLINET publishing group 2000-2010, Adam, M., AladosArboledas, L., Althausen, D., Amiridis, V., Amodeo, A., Ansmann, A., Apituley, A., Arshinov, Y., Balis, D., Belegante, L., Bobrovnikov, S., Boselli, A., Bravo-Aranda, J. A., Bösenberg,J., Carstea, E., Chaikovsky, A., Comerón, A., D’Amico, G., Daou, D., Dreischuh, T., Engelmann, R., Finger, F., Freudenthaler, V., Garcia-Vizcaino, D., García, A. J. F., Geiß, A., Giannakaki, E., Giehl, H., Giunta, A., de Graaf, M., GranadosMuñoz, M. J., Grein, M., Grigorov, I., Groß, S., Gruening, C., Guerrero-Rascado, J. L., Haeffelin, M., Hayek, T., Iarlori, 
M.,Kanitz, T., Kokkalis, P., Linné, H., Madonna, F., Mamouriat, R.-E., Matthias, V., Mattis, I., Menéndez, F. M., Mitev, V., Mona, L., Morille, Y., Muñoz, C., Müller, A., Müller, D., NavasGuzmán, F., Nemuc, A., Nicolae, D., Pandolfi, M., Papayannis,A., Pappalardo, G., Pelon, J., Perrone, M. R., Pietruczuk,A., Pisani, G., Potma, C., Preißler, J., Pujadas, M., Putaud, J., Radu, C., Ravetta, F., Reigert, A., Rizi, V., Rocadenbosch, F., Rodríguez, A., Sauvage, L., Schmidt, J., Schnell, F., Schwarz,A., Seifert, P., Serikov, I., Sicard, M., Silva, A. M., Simeonov,V., Siomos, N., Sirch, T., Spinelli, N., Stoyanov, D., Talianu, C., Tesche, M., De Tomasi, F., Trickl, T., Vaughan, G., Volten, H., Wagner, F., Wandinger, U., Wang, X., Wiegner, M., and Wilson, K. M.: EARLINET observations related to volcanic eruptions (2000-2010), World Data Center for Climate (WDCC), doi:10.1594/WDCC/EN_VolcanicEruption_2000-2010, 2014.

Emeis, S., Forkel, R., Junkermann, W., Schäfer, K., Flentje, H., Gilge, S., Fricke, W., Wiegner, M., Freudenthaler, V., Groß, S., Ries, L., Meinhardt, F., Birmili, W., Münkel, C., Obleitner, F., and Suppan, P.: Measurement and simulation of the 16/17 April 2010 Eyjafjallajökull volcanic ash layer dispersion in the northern Alpine region, Atmos. Chem. Phys., 11, 26892701, doi:10.5194/acp-11-2689-2011, 2011.

Francis, P. N., Cooke, M. C., and Saunders, R. W.: Retrieval of physical properties of volcanic ash using Meteosat: A case study from the 2010 Eyjafjallajökull eruption, J. Geophys. Res., 117, D00U09, doi:10.1029/2011JD016788, 2012.

Freudenthaler, V., Gross, S., Engelmann, R., Mattis, I., Wandinger, U., Pappalardo, G., Amodeo, A., Giunta, A., D’Amico, G., Chaikovsky, A., Osipenko, F., Slesar, A., Nicolae, D., Belegante, L., Talianu, C., Serikov, I., Linne, H., Jansen, F., Wilson, K., de Graaf, M., Apituley, A., Trickl, T., Giehl, H., and Adam, M.: EARLI09 - direct intercomparison of eleven EARLINET lidar systems, in: Proceedings of the 25th International Laser Radar Conference, 5-9 July 2010, St. Petersburg, Russia, 891-894, 2010.

Gangale, G., Prata, A. J., and Clarisse, L.: The infrared spectral signature of volcanic ash determined from high spectral resolution satellite measurements, Remote Sens. Environ., 114, 414-425, doi:10.1016/j.rse.2009.09.007, 2010.

Gertisser, R.: Eyjafjallajökull causes widespread disruption to European air traffic, Geol. Today, 26, 94-95, 2010.

Giannakaki, E., Balis, D. S., Amiridis, V., and Kazadzis, S.: Optical and geometrical characteristics of cirrus clouds over a Southern European lidar station, Atmos. Chem. Phys., 7, 5519-5530, doi:10.5194/acp-7-5519-2007, 2007.

Grainger, R. G., Peters, D. M., Thomas, G. E., Smith, A., Siddans, R., Carboni, E., and Dudhia, A.: Measuring volcanic plume and ash properties from space, in remote sensing of volcanoes and volcanic processes: Integrating observation and modelling, Geol. Soc. Spec. Publ., 380, 293-320, doi:10.1144/SP380.7, 2013.

Groß, S., Freudenthaler, V., Wiegner, M., Gasteiger, J., Geiß, A., and Schnell, F.: Dual-wavelength linear depolarization ratio of volcanic aerosols: lidar measurements of the Eyjafjallajökull plume over Maisach, Germany, Atmos. Environ., 48, 85-96, doi:10.1016/j.atmosenv.2011.06.017, 2011.

Gudmundsson, M. T., Pedersen, R., Vogfjörd, K., Thorbjarnardóttir, B., Jakobsdóttir, S., and Roberts, M. J.: Eruptions of Eyjafjallajökull Volcano, Iceland, Eos Trans. AGU, 91, 190-191, doi:10.1029/2010EO210002, 2010.
Guerrero-Rascado, J. L., Olmo, F. J., Avilés-Rodríguez, I., NavasGuzmán, F., Pérez-Ramírez, D., Lyamani, H., and Alados Arboledas, L.: Extreme Saharan dust event over the southern Iberian Peninsula in September 2007: active and passive remote sensing from surface and satellite, Atmos. Chem. Phys., 9, 84538469, doi:10.5194/acp-9-8453-2009, 2009.

Guffanti, M., Schneider, D. J., Wallace, K. L., Hall, T., Bensimon, D. R., and Salinas, L. J.: Aviation response to widely dispersed volcanic ash and gas cloud from the August 2008 eruption of Kasatochi, Alaska, USA, J. Geophys. Res., 115, D00L19, doi:10.1029/2010JD013868, 2010.

Herman, J. R., Bhartia, P. K. , Torres, O. , Hsu, C., Seftor, C., and Celarier, E.: Global distributions of UV-absorbing aerosols from Nimbus 7/TOMS data, J. Geophys. Res., 102, 16911-16922, doi:10.1029/96JD03680, 1997.

Johnson, B. T., Turnbull, K. F., Dorsey, J., Baran, A. K.,Ulanowski, Z., Hesse, E., Cotton, R., Brown, P. R. A., Burgess, R., Capes, G., Webster, H. N., Woolley, A. M., Rosenberg, P. D., and Haywood, J. M.: In situ observations of volcanic ash clouds from the FAAM aircraft during the eruption of Eyjafjallajökull in 2010, J. Geophys. Res., 117, D00U24, doi:10.1029/2011JD016760, 2011.

Koukouli, M. E., Clarisse, L., Carboni, E., van Gent, J., Spinetti, C., Balis, D., Dimopoulos, S., Grainger, R. G., Theys, N., Tampellini, L., and Zehner, C.: Intercomparison of Metop-A $\mathrm{SO}_{2}$ measurements during the 2010-2011 Icelandic eruptions, Annals in Geophysics, 57, Fast Track 2, 1-6, doi:10.4401/ag-6613, 2014a.

Koukouli, M. E., Balis, D., Dimopoulos, S., and Siomos, N.: SACS2/SMASH Validation Report on the Eyjafjallajökull \& Grímsvötn Eruptions, available at: http://sacs.aeronomie.be/ Documentation/LAP-AUTH-SACS-ValidationReport_FINAL. pdf (last access: 5 May 2016), 2014b.

Mamouri, R. E., Papayannis, A., Amiridis, V., Müller, D., Kokkalis, P., Rapsomanikis, S., Karageorgos, E. T., Tsaknakis, G., Nenes, A., Kazadzis, S., and Remoundaki, E.: Multi-wavelength Raman lidar, sun photometric and aircraft measurements in combination with inversion models for the estimation of the aerosol optical and physico-chemical properties over Athens, Greece, Atmos. Meas. Tech., 5, 1793-1808, doi:10.5194/amt-5-1793-2012, 2012.

Marenco F., Johnson, B., Turnbull, K., Newman, S., Haywood, J., Webster, H., and Ricketts, H.: Airborne lidar observations of the 2010 Eyjafjallajökull volcanic ash plume, J. Geophys. Res., 116, D00U05, doi:10.1029/2011JD016396, 2011.

Matthias, V., Bösenberg, J., Freudenthaler, V., Amodeo, A., Balis, D., Chaikovsky, A., Chourdakis, G., Comeron, A., Delaval, A., de Tomasi, F., Eixmann, R., Hågård, A., Komguem, L., Kreipl, S., Matthey, R., Mattis, I., Rizi, V., Rodriguez, J. A., Simeonov, V., and Wang, X.: Aerosol lidar intercomparison in the framework of the EARLINET project. 1. Instruments, Appl. Optics 43, 961-976, 2004a.

Matthias, V., Balis, D., Bösenberg, J., Eixmann, R., Iarlori, M., Komguem, L., Mattis, I., Papayannis, A., Pappalardo, G., Perrone, M. R., and Wang, X.: Vertical aerosol distribution over Europe: Statistical analysis of Raman lidar data from 10 European Aerosol Research Lidar Network (EARLINET) stations, J. Geophys. Res.-Atmos., 109, D18201, doi:10.1029/2004JD004638, 2004b. 
Mattis, I., Siefert, P., Müller, D., Tesche, M., Hiebsch, A., Kanitz, T., Schmidt, J., Finger, F., Wandinger, U., and Ansmann, A.: Volcanic aerosol layers observed with multiwavelength Raman lidar over central Europe in 2008-2009, J. Geophys. Res., 115, D00L04, doi:10.1029/2009JD013472, 2010.

Mona L., Amodeo, A., Pandolfi, M., and Pappalardo, G.: Saharan dust intrusions in the Mediterranean area: three years of lidar measurements in Potenza, J. Geophys. Res., 111, D16203, doi:10.1029/2005JD006569, 2006.

Mona, L., Amodeo, A., D’Amico, G., Giunta, A., Madonna, F., and Pappalardo, G.: Multi-wavelength Raman lidar observations of the Eyjafjallajökull volcanic cloud over Potenza, southern Italy, Atmos. Chem. Phys., 12, 2229-2244, doi:10.5194/acp-12-22292012, 2012.

Moxnes, E. D., Kristiansen, N. I., Stohl, A., Clarisse, L., Durant, A., Weber, K., and Vogel, A.: Separation of ash and sulfur dioxide during the 2011 Grímsvötn eruption, J. Geophys. Res.-Atmos., 119, 7477-7501, doi:10.1002/2013JD021129, 2014.

Müller, D., Mattis, I., Ansmann, A., Wandinger, U., Ritter, C., and Kaiser, D.: Multiwavelength Raman lidar observations of particle growth during long-range transport of forest-fire smoke in the free trosposphere. Geophys. Res. Lett., 34, L05803, doi:10.1029/2006GL027936, 2007.

Navas-Guzman, F., Müller, D., Bravo-Aranda, J. A., GuerreroRascado, J. L., Granados-Munoz, M. J., Perez-Ramirez, D., Olmo, F. J., and Alados-Arboledas, L.: Eruption of the Eyjafjallajökull Volcano in spring 2010: Multiwavelength Raman lidar measurements of sulphate particles in the lower troposphere, J. Geophys. Res., 118, 1804-1813, doi:10.1002/jgrd.50116, 2013.

Papayannis, A., Amiridis, V., Tsaknakis, G., Balis, D., Bösenberg, J., Chaikovski, A., De Tomasi, F., Grigorov, I., Mattis, I., Mitev, V., Müller, D., Mona, L., Nickovic, S., Pérez, C., Pietruczuk, A., Pisani, G., Ravetta, F., Rizi, V., Sicard, M., Trickl, T., Wiegner, M., and Eixmann, R.: Systematic lidar observations of Saharan dust over Europe in the frame of EARLINET (2000-2002), J. Geophys. Res., 113, D10204, doi:10.1029/2007JD009028, 2008.

Papayannis, A., Mamouri, R. E., Amiridis, V., Giannakaki, E., Veselovski, I., Kokkalis, P., Tsaknakis, G., Balis, D., Kristiansen, N. I., Stohl, A., Korenskiy, M., Allakhverdiev, K., Huseyinoglu, M. F., and Baykaral, T.: Optical properties and vertical extension of aged ash layers over the Eastern Mediterranean as observed by Raman lidars during the Eyjafjallajökull eruption in May 2010, Atmos. Environ., 48, 56-65, doi:10.1016/j.atmosenv.2011.08.037, 2012.

Pappalardo, G., Amodeo, A., Pandolfi, M., Wandinger, U., Ansmann, A., Bosenberg, J., Matthias, V., Amiridis, V., De Tomasi, F., Frioud, M., Iarlori, M., Komguem, L., Papayannis, A., Rocadenbosch, F., and Wang, X.: Aerosol lidar intercomparison in the framework of the EARLINET project. 3. Raman lidar algorithm for aerosol extinction, backscatter and lidar ratio, Appl. Optics, 43, 5370-5385, doi:10.1364/AO.43.005370, 2004.

Pappalardo, G., Mona, L., D’Amico, G., Wandinger, U., Adam, M., Amodeo, A., Ansmann, A., Apituley, A., Alados Arboledas, L., Balis, D., Boselli, A., Bravo-Aranda, J. A., Chaikovsky, A., Comeron, A., Cuesta, J., De Tomasi, F., Freudenthaler, V., Gausa, M., Giannakaki, E., Giehl, H., Giunta, A., Grigorov, I., Groß, S., Haeffelin, M., Hiebsch, A., Iarlori, M., Lange, D., Linné, H., Madonna, F., Mattis, I., Mamouri, R.-E., McAuliffe, M. A. P., Mitev, V., Molero, F., Navas-Guzman, F., Nicolae, D., Pa- payannis, A., Perrone, M. R., Pietras, C., Pietruczuk, A., Pisani, G., Preißler, J., Pujadas, M., Rizi, V., Ruth, A. A., Schmidt, J., Schnell, F., Seifert, P., Serikov, I., Sicard, M., Simeonov, V., Spinelli, N., Stebel, K., Tesche, M., Trickl, T., Wang, X., Wagner, F., Wiegner, M., and Wilson, K. M.: Four-dimensional distribution of the 2010 Eyjafjallajökull volcanic cloud over Europe observed by EARLINET, Atmos. Chem. Phys., 13, 4429-4450, doi:10.5194/acp-13-4429-2013, 2013.

Pappalardo, G., Amodeo, A., Apituley, A., Comeron, A., Freudenthaler, V., Linné, H., Ansmann, A., Bösenberg, J., D’Amico, G., Mattis, I., Mona, L., Wandinger, U., Amiridis, V., AladosArboledas, L., Nicolae, D., and Wiegner, M.: EARLINET: towards an advanced sustainable European aerosol lidar network, Atmos. Meas. Tech., 7, 2389-2409, doi:10.5194/amt-7-23892014, 2014.

Perrone, M. R., De Tomasi, F., Stohl, A., and Kristiansen, N. I.: Integration of measurements and model simulations to characterize Eyjafjallajökull volcanic aerosols over south-eastern Italy, Atmos. Chem. Phys., 12, 10001-10013, doi:10.5194/acp-1210001-2012, 2012.

Pollack, J., Toon, O., and Khare, B.: Optical properties of some terrestrial rocks and glasses, Icarus, 19, 372-389, 1973.

Prata, A. J. and Prata, A. T.: Eyjafjallajökull volcanic ash concentrations determined using Spin Enhanced Visible and Infrared Imager measurements, J. Geophys. Res., 117, D00U23, doi:10.1029/2011JD016800, 2012.

Rix, M., Valks, P., Hao, N., Loyola, D., Schlager, H., Huntrieser, H., Flemming, J., Koehler, U., Schumann, U., and Inness, A.: Volcanic $\mathrm{SO}_{2}, \mathrm{BrO}$ and plume height estimations using GOME-2 satellite measurements during the eruption of Eyjafjallajökull in May 2010, J. Geophys. Res., 117, D00U19, doi:10.1029/2011JD016718, 2012.

Schumann, U., Weinzierl, B., Reitebuch, O., Schlager, H., Minikin, A., Forster, C., Baumann, R., Sailer, T., Graf, K., Mannstein, H., Voigt, C., Rahm, S., Simmet, R., Scheibe, M., Lichtenstern, M., Stock, P., Rüba, H., Schäuble, D., Tafferner, A., Rautenhaus, M., Gerz, T., Ziereis, H., Krautstrunk, M., Mallaun, C., Gayet, J.F., Lieke, K., Kandler, K., Ebert, M., Weinbruch, S., Stohl, A., Gasteiger, J., Groß, S., Freudenthaler, V., Wiegner, M., Ansmann, A., Tesche, M., Olafsson, H., and Sturm, K.: Airborne observations of the Eyjafjalla volcano ash cloud over Europe during air space closure in April and May 2010, Atmos. Chem. Phys., 11, 2245-2279, doi:10.5194/acp-11-2245-2011, 2011.

Sears, T. M., Thomas, G. E., Carboni, E., Smith, A. J. A., and Grainger, R. G.: $\mathrm{SO}_{2}$ as a possible proxy for volcanic ash in aviation hazard avoidance, J. Geophys. Res.-Atmos., 118, 56985709, doi:10.1002/jgrd.50505, 2013.

Sinyuk, A., Torres, O., and Dubovik, O.: Combined use of satellite and surface observations to infer the imaginary part of refractive index of Saharan dust, Geophys. Res. Lett., 30, 1081, doi:10.1029/2002GL016189, 2003.

Spinetti C, Salerno, G., Caltabiano, T., Carboni, E., Clarisse, L., Corradini, S., Grainger, R. G., Hedelt, P., Koukouli, M. E., Merucci, L., Siddans, R., Tampellini, L., Theys, N., Valks, P., and Zehner, C.: Volcanic $\mathrm{SO}_{2}$ by UV-TIR satellite retrievals: validation by using ground-based network at Mt. Etna, Annals in Geophysics, 57, Fast Track 2, 1-6, doi:10.4401/ag-6641, 2014.

Stohl, A., Prata, A. J., Eckhardt, S., Clarisse, L., Durant, A., Henne, S., Kristiansen, N. I., Minikin, A., Schumann, U., Seibert, P., 
Stebel, K., Thomas, H. E., Thorsteinsson, T., Tørseth, K., and Weinzierl, B.: Determination of time- and height-resolved volcanic ash emissions and their use for quantitative ash dispersion modeling: the 2010 Eyjafjallajökull eruption, Atmos. Chem. Phys., 11, 4333-4351, doi:10.5194/acp-11-4333-2011, 2011.

Thomas, G. E., Poulsen, C. A., Sayer, A. M., Marsh, S. H., Dean, S. M., Carboni, E., Siddans, R., Grainger, R. G., and Lawrence, B. N.: The GRAPE aerosol retrieval algorithm, Atmos. Meas. Tech., 2, 679-701, doi:10.5194/amt-2-679-2009, 2009a.

Thomas, G. E., Carboni, E., Sayer, A. M., Poulsen, C. A., Siddans, R., and Grainger, R. G.: Oxford-RAL Aerosol and Cloud (ORAC): aerosol retrievals from satellite radiometers in Satellite Aerosol Remote Sensing Over Land, edited by: Kokhanovsky, A. A. and de Leeuw, G., Springer - Praxis Publishing Ltd, Chichester, UK, 193-225, 2009b.

Torres, O., Bhartia, P. K., Herman, J. R., Ahmad, Z., and Gleason, J.: Derivation of aerosol properties from satellite measurements of backscattered ultraviolet radiation: theoretical basis, J. Geophys. Res., 103, 17099-17110, doi:10.1029/98JD00900, 1998.

Trickl, T., Giehl, H., Jäger, H., and Vogelmann, H.: 35 yr of stratospheric aerosol measurements at Garmisch-Partenkirchen: from Fuego to Eyjafjallajökull, and beyond, Atmos. Chem. Phys., 13, 5205-5225, doi:10.5194/acp-13-5205-2013, 2013.

Ventress, L. J., Carboni, E., Grainger, R. G., and Smith, A. J.: Retrieval of ash optical properties form IASI measurements, Atmos. Chem. Phys, in preparation, 2016.

Volz, F. E.: Infrared optical constants of ammonium sulfate, Sahara dust, volcanic pumice and fly ash, Appl. Optics, 12, 564-568, 1973.

Walker, J. C., Dudhia, A., and Carboni, E.: An effective method for the detection of trace species demonstrated using the MetOp Infrared Atmospheric Sounding Interferometer, Atmos. Meas. Tech., 4, 1567-1580, doi:10.5194/amt-4-1567-2011, 2011.

Wandinger, U., Freudenthaler, V., Baars, H., Amodeo, A., Engelmann, R., Mattis, I., Groß, S., Pappalardo, G., Giunta, A., D’Amico, G., Chaikovsky, A., Osipenko, F., Slesar, A., Nicolae, D., Belegante, L., Talianu, C., Serikov, I., Linné, H., Jansen, F., Apituley, A., Wilson, K. M., de Graaf, M., Trickl, T., Giehl, H., Adam, M., Comerón, A., Muñoz-Porcar, C., Rocadenbosch, F., Sicard, M., Tomás, S., Lange, D., Kumar, D., Pujadas, M., Molero, F., Fernández, A. J., Alados-Arboledas, L., Bravo-Aranda, J. A., Navas-Guzmán, F., Guerrero-Rascado, J. L., Granados-Muñoz, M. J., Preißler, J., Wagner, F., Gausa, M., Grigorov, I., Stoyanov, D., Iarlori, M., Rizi, V., Spinelli, N., Boselli, A., Wang, X., Lo Feudo, T., Perrone, M. R., De Tomasi, F., and Burlizzi, P.: EARLINET instrument intercomparison campaigns: overview on strategy and results, Atmos. Meas. Tech., 9, 1001-1023, doi:10.5194/amt-9-1001-2016, 2016.
Wang, P., Stammes, P., van der A, R., Pinardi, G., and van Roozendael, M.: FRESCO+: an improved $\mathrm{O}_{2}$ A-band cloud retrieval algorithm for tropospheric trace gas retrievals, Atmos. Chem. Phys., 8, 6565-6576, doi:10.5194/acp-8-6565-2008, 2008.

Wang, P., Tuinder, O. N. E., Tilstra, L. G., de Graaf, M., and Stammes, P.: Interpretation of FRESCO cloud retrievals in case of absorbing aerosol events, Atmos. Chem. Phys., 12, 90579077, doi:10.5194/acp-12-9057-2012, 2012.

Wang, X., Boselli, A., D’Avino, L., Pisani, G., Spinelli, N., Amodeo, A., Chaikovsky, A., Wiegner, M., Nickovic, S., Papayannis, A., Perrone, M. R., Rizi, V., Sauvage, L., and Stohl, A.: Volcanic dust characterization by EARLINET during Etna's eruptions in 2001-2002, Atmos. Environ., 42, 893-905, 2008.

Wiegner, M., Gasteiger, J., Groß, S., Schnell, F., Freudenthaler, V., and Forkel, R.: Characterization of the Eyjafjallajökull ashplume: Potential of lidar remote sensing, Phys. Chem. Earth, 4546, 79-86, doi:10.1016/j.pce.2011.01.006, 2012.

Winker, D. M., Liu, Z., Omar, A., Tackett, J., and Fairlie, D.: CALIOP observations of the transport of ash from the Eyjafjallajökull volcano in April 2010, J. Geophys. Res., 117, D00U15, doi:10.1029/2011JD016499, 2012.

World Meteorological Organization: WMO SCOPENowcasting: Meeting on the Intercomparison of Satellite based Volcanic Ash Retrieval Algorithms, 29 June2 July 2015, Madison, WI, USA, Final Report, available at: http://www.wmo.int/pages/prog/sat/documents/ SCOPE-NWC-PP2_VAIntercompWSReport2015.pdf (last access: 5 May 2016), 2015.

Zehner, C. (Ed.): Monitoring Volcanic Ash from Space, Proceedings of the ESA-EUMETSAT workshop on the 14 April to 23 May 2010 eruption at the Eyjafjoll volcano, South Iceland, 26-27 May 2010, Frascati, Italy, ESA-Publication STM-280, available at: http://earth.esa.int/workshops/Volcano/files/STM_ 280_web.pdf (last access: 9 May 2016), 2012. 